doi: 10.18575/msrs.sm.e.18.11

UDC: 616.36-004-06

COBISS.RS-ID: 7318808

\title{
Surgical Treatment of Spontaneous Spleen Rupture in Patients with Splenomegalia
}

\begin{abstract}
Spontaneous spleen rupture rarely occurs, and is primarily present in patients with splenomegaly. This is a life-threatening condition that, without adequate surgical treatment, always ends lethally. The very etiology of spontaneous atriumatic spleen rupture is not known, but it can often be associated with neoplastic diseases, liver cirrhosis, and some infectious diseases. Diagnosis is made by non-invasive methods (findings of red blood cell elements, ultrasonography, computerized tomography of abdominal CT, magnetic resonance NMR). The therapy consists of laparotomy, evacuation of the haemorrhagic content and removal of the spleen. Surgical treatment is successful, and as a postoperative complication, bleeding may occur as a result of inadequate care of the laryngeal artery and vein, and short gastric blood vessels. Here we presented a 58- year- old male patient who, due to a marked abdominal pain, low blood pressure, and low blood cell counts, was taken to hospital and successfully surgically treated at the Clinic for General and Abdominal Surgery.
\end{abstract}

Key words: splenomegaly, spleen rupture, haemorrhagic shock, splenectomy.

(Scr Med 2018:49:65-68)

\section{Jugoslav Đeri', Milan Simatović, Vojo Vujanović ${ }^{2}$, Duško Topić ${ }^{1}$}

${ }^{1}$ Clinic of General and Abdominal Surgery, University Clinical Center of the Republic of Srpska, Banja Luka

${ }^{2}$ Clinic of Anesthesia and Reanimation, University Clinical Center of the Republic of Srpska, Banja Luka

\section{Contact address: Jugoslav Đeri Street address: Nikole Pašića 36 $780 o$ o Banja Luka Republic of Srpska Bosnia and Herzegovina e-mail:djeri@blic.net phone number: +387-65-601-777}

Submitted: March 15 $5^{\text {th }}, 2018$ Accepted: March 25 $5^{\text {th }}, 2018$

\section{Introduction}

The destruction of parenchyma, capsules, or blood vessels is a spleen condition called rupture. Spleen may rupture spontaneously, but spontaneous rupture of the spleen is very rare and is most common in malaria, mononucleosis, lymphoma, leukemia and other conditions followed by enlargement of the spleen.1 In recent times, fewer spontaneous ruptures occur in patients on anticoagulation-antiagregation therapy.2 The exact mechanism of spontaneous spleen rupture is unknown, and the clinical picture may vary from severe hypovolemic shock to minimal symptoms. In the earlier period, the mortality of these patients was very high due to complications and difficult diagnosis, and the main cause of mortality was hypovolemic shock due to the loss of large amounts of blood.
Figure 1. CT Image of Enlarged Spleen

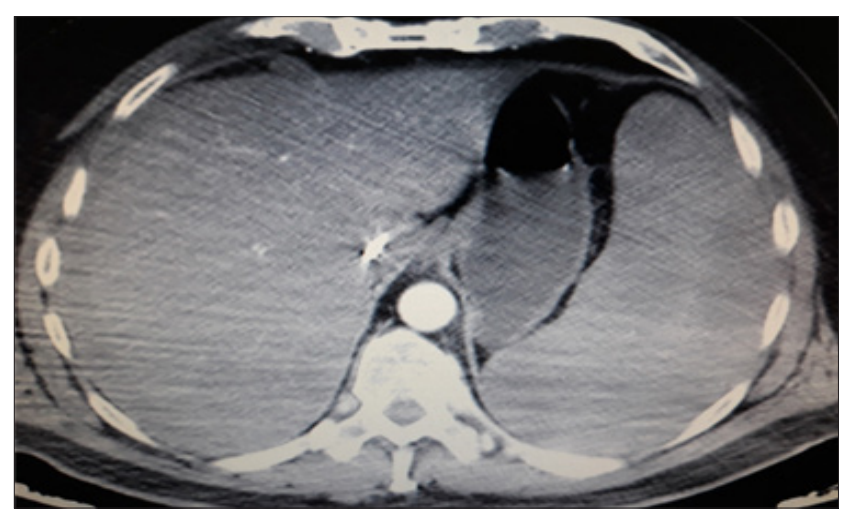

Today, due to significant advances in diagnostic 
procedures, primarily by the introduction of $\mathrm{CT}$ and NMR abdominal (Fig. 1), mortality has been significantly reduced. ${ }^{3}$ Disposing of a patient with rupture may require surgical or non-operative treatment, which is assessed on the basis of general condition, vital parameters and clinical picture.

\section{Case report}

In the intensive care unit (ICU), a 58-year-old patient was admitted due to anxiety pain, pain in the upper abdomen and weaknesses. Until that moment, the patient was suffering from anxiety and did not use the therapy. Insights into the medical records of the patient did not establish the existence of any cardiological or chronic illness. Also, the patient denied any kind of trauma. By physical examination, a pulse of 110 beats per minute was established and a blood pressure value of 115 / 70mmHg. Peripheral blood results showed the value of red blood cell (Er) 3.1, hemoglobin (Hgb) $95 \mathrm{~g}$ / l, platelets (PLT) 58x109. The patient was given an IV solution therapy and he underwent detailed diagnostic treatment. An emergency CT of abdominal and chest bone was performed in the patient. The enlarged spleen with the capsules lesions and the presence of free fluid in the abdominal density of the blood were found. According to the findings, the patient was appointed to surgery, where a patient in a conscious but poor general condition, is admitted into an intensive care unit. The patient repeated the peripheral blood analyses, which showed results of decreasing values and the same was administered with two doses of blood. Based on the insight into the medical documentation and the general condition of the patient, a decision for surgical treatment was made.

Figure 2. Removed Raptured Spleen

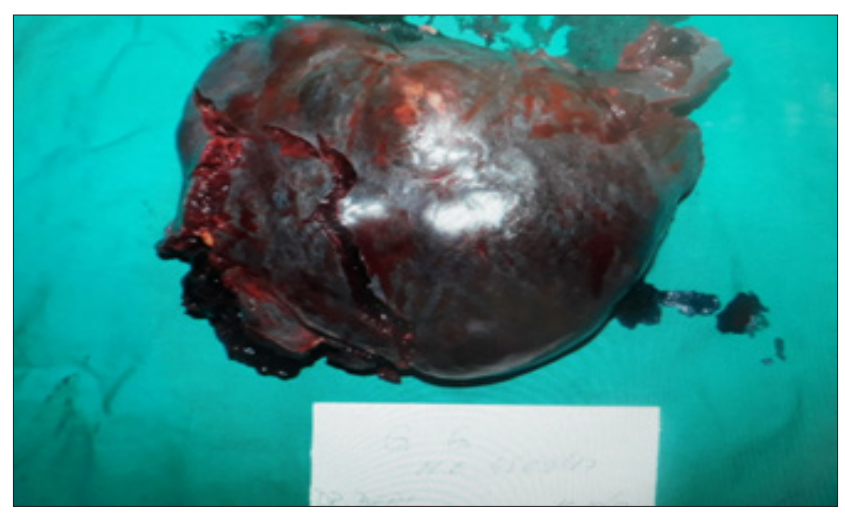

The patient was introduced into the general endotracheal anesthesia, and then the upper medial laparatomy was made, the abdominal cavity was entered, where the enlarged spleen with rupture was noted as well as higher amount of free blood that filled the upper and lower part of the abdominal cavity. (Fig. 2)

Evacuation of blood from the abdominal cavity was done, and arteries and venous lienalis were reconverted, ligated and then resected. Then, the preparation and treatment of short gastric blood vessels was done, and this kind of uncompressed and released spleen was removed from the abdominal cavity. After the evacuation of the spleen, the abdominal cavity was rinsed, and the adhesive hemostase and drainage with two abdominal drains were done. One of the drains was placed in the place of the removed spleen and the other in the Douglas tread. The abdomen was sealed in anatomical layers and the patient was transferred the Intensive Care Unit (ICU) for further treatment. After 24 hours, the patient's condition was stable with stable blood references, on the abdominal drains a smaller amount of bloody rinsing was present and the patient was transferred to the General Surgery Clinic for further treatment. The patient situated in the ward was examined by a hematologist who, on the basis of a clinical examination and obtained blood tests, excluded the existence of a hematological disorder. An early postoperative course passed neatly, the control findings of the blood tests were regular and the patient was released home in good general condition.

\section{Discussion}

Spontaneous atraumatic spleen rupture is a rare, but serious clinical event requiring urgent surgical intervention to save the patient's life. However, in a small number of cases where the patient's condition is stable and there is no deterioration of vital parameters, treatment can be conservative. ${ }^{4}$ Although spontaneous spleen rupture rarely occurs, it is mainly associated with a neoplastic process (30\%), an infectious process (27\%), an inflammatory non-infectious process (20\%) but can also occur in a fully healthy spleen (6\%). ${ }^{5}$ In a study published by Kapan and authors, it was found that the use of anticoagulant-anti-aggregation therapy in $33 \%$ of cases was the cause of spontaneous spleen rupture. ${ }^{6}$

In our patient's presentation, no histological change or an etiological factor was found to be the cause of spontaneous spleen rupture. Also in the study conducted by Koceal and authors, there were examples of spontaneous spleen rupture that occurred without the established cause of rupture with a representation of $8 \%$ of cases. Such cases of spontaneous rupture are considered idiopathic. ${ }^{7}$ However, despite all the known causes of spontaneous spleen rupture, the mechanism of spontaneous rupture itself has not been fully clarified.

It is believed that there are three possible mechanisms of rupture formation, namely distension due to enlargement 
of the spleen and spraying of the capsule, spleen infarction with consequent rupture and defect of blood coagulation with rupture. The main clinical symptoms of spleen rupture are abdominal pain, hypotension, nausea, dizziness. Also well-known are the Kehr's sign (left diaphragmatic irritation with the spread of pain in the left shoulder) and Balance's sign (tangible mass in the left upper quadrant of the abdomen. ${ }^{8}$ Nevertheless, despite these clinical symptoms, a definite diagnosis of spleen rupture can only be made on the basis of findings from the US and CT abdomens. ${ }^{9}$ In our case, based on the clinical picture and laboratory diagnosis, it was suspected of cardiac disease, but the definitive diagnosis was based on the CT abdomen and chest.

After the diagnosis of spontaneous rupture of the spleen and assessment of the general condition of patients, it is approached to the treatment. The treatment of haemodynamically stable patients with minor rupture caused by infectious diseases is generally conservative, and the success of conservative treatment ranges up to $80 \% .5$ In addition to conservative treatment in haemodynamically stable patients, arterial embolization10 has been used with recent success. However, in all haemodynamically unstable patients, with whom general conditions are aggravated, an emergency surgical treatment involving splenectomy, is indicated. Splenectomy is a classic treatment because it removes the source of bleeding and allows exploration of the abdominal cavity. Surgery, splenectomy, ranges from $84 \%$ to $91 \%$ in numerous studies. ${ }^{11}$ In our case, due to the deterioration of general conditions of the patient and further decline of the blood test, an emergency splenectomy was reported, after which a successful recovery of the patient occurred. Mortality in patients with spontaneous rupture of the spleen ranged to $12.2 \%$, and it was found that mortality was increasing in patients with neoplastic diseases and in patients over 40 years of age. ${ }^{5}$

\section{Conclusion}

Based on all previously said, it follows that spontaneous rupture of the spleen is rare but life-threatening condition, with a high mortality rate if complete diagnosis and adequate therapy is not performed. In most cases, surgical treatment involving spleen removal is the main therapeutic procedure.

\section{References}

1. Lawrence W.Way Hirurgija savremena dijagnostika i liječenje. Savremena administracija Beograd 1990; 265682.

2. Lowry LE1, Goldner JA2. J Med Case Rep. Spontaneous splenic rupture associated with apixaban: a case report. 2016 Aug 9;10(1):217. doi: 10.1186/s13256-016-1012-6.

3. Zhang Y1, Zhang J1, Chen T1, Zeng H1, Zhao B1, Zhang $\mathrm{Y} 1$ at al. Mol Clin Oncol. Spontaneous splenic rupture in an acute leukemia patient with splenic tuberculosis. 2017 Feb;6(2):209-213.

4. Mohammed AM, Majid ZI, Villatoro EA Spontaneous rupture of the spleen as a result of primary splenic lymphoma. .J Surg Case Rep. 2016 Jan 1;2016(1). pii:rjv164. https://doi.org/10.1093/jscr/rjv164

5. Renzulli P, Hostettler A, Schoepfer AM, Gloor B, Candinas D. Systematic review of atraumatic splenic rupture. Br J Surg. 2009;96:1114-1121.

6. Kapan M, Kapan S, Karabicak I, Bavunoglu I. Simultaneous rupture of the liver and spleen in a patient on warfarin therapy: report of a case. Surg Today. 2005;35(3):252255.

https://doi.org/10.1007/s00595-004-2898-y PMid:15772800

7. Kocael PC1, Simsek O, Bilgin IA, Tutar O, Saribeyoglu K, Pekmezci S, Goksoy E Characteristics of patients with spontaneous splenic rupture. Int Surg. 2014 NovDec;99(6):714-8.

https://doi.org/10.9738/INTSURG-D-14-00143.1

PMid:25437576

PMCid:PMC4254229

8. Roche M, Maloku F, Abdel-Aziz TE . An unusual diagnosis of splenic rupture. BMJ Case Rep. 2014 Oct 7;2014. pii: bcr2014204891. doi: 10.1136/bcr-2014-204891.

9. Pluut OA1, Holman ND, Rödel SG. Spontaneous, atraumatic rupture of the spleen in a young man. Ned Tijdschr Geneeskd. 2015;159:A8392 PMid:25873218

10. Lin WC, Chen YF, Tzeng YH, et al. Emergent transcatheter arterial embolisation in haemodynamically unstable patients with blunt splenic injury. Acad Radiol 2008;15:201-8.

https://doi.org/10.1016/j.acra.2007.09.010 PMid:18206619

11. Hadary A, Dashkovsky I, Rapaport A, Cozakov JC. Nontraumatic rupture of spleen: can splenectomy be applied selectively? Isr Med Assoc J. 2008;10(12):889-891 PMid:19160949 


\title{
Hirurško zbrinjavanje spontane rupture slezene kod pacijenta sa splenomegalijom
}

\begin{abstract}
SAŽETAK
Spontana ruptura slezene se rijetko javlja i prvenstveno je zastupljena kod pacijenata sa splenomegalijom. To je po život opasno stanje koje se bez adekvatnog hirurškog tretmana uvijek završava letalno. Sama etiologija spontane atraumatske rupture slezene nije poznata, ali se ona često može povezati sa neoplastičnim oboljenjima, cirozom jetre i nekim infektivnim oboljenjima. Dijagnoza se postavlja neinvazivnim metodama (nalazima elemenata crvene krvne loze, ultrasonografija, kompjuterizovana tomografija abdomena CT, magnetna rezonanca NMR). Terapija se sastoji od laparatomije, evakuacije hemoragičnog sadržaja i uklanjanja slezene. Hirurško liječenje je uspješno, a kao postoperativna komplikacija se može javiti krvarenje kao posljedica neadekvatnog zbrinjavanja lijenalne arterije i vene, te kratkih gastričnih krvnih sudova. Ovdje smo prikazali 58-ogodišnjeg pacijenta muškog pola, koji je zbog izraženog abdominalnog bola, malaksalosti, te niske vrijednosti krvne slike primljen i uspješno hirurški zbrinut na Klinici za opštu i abdominalnu hirurgiju.
\end{abstract}

Ključne riječi: Splenomegalija, ruptura slezene, hemoragijski šok, splenektomija 